\title{
Some aspects of soil and seed pre-treatments on germination, growth and biomass production of Tamarindus indica seeds in the nursery
}

\author{
Noah Alabi Oyebamiji ${ }^{*}$ Abraham Adikpe Ogo ${ }^{1}$ \\ ${ }^{1}$ Federal University Dutsin-Ma, Katsina State, Nigeria \\ *Author for correspondence: noyebamiji@fudutsinma.edu.ng \\ Received: November 2018/ Accepted: February 2019 / Published: March 2019
}

\begin{abstract}
Tamarind is a multipurpose plant. Hence, the study investigated soil and seed pre-treatments on germination, growth and biomass production of Tamarindus indica seeds in a nursery. Completely Randomized Design with four replicates was adopted and data were analysed using Analysis of Variance. Mechanically scarified seeds (MS) sowed in top soil $\left(\mathrm{S}_{1}\right)$, river sand $\left(\mathrm{S}_{2}\right)$, top soil plus river sand plus manure $\left(\mathrm{S}_{3}\right)\left(\mathrm{S}_{1} \mathrm{MS}\right),\left(\mathrm{S}_{2} \mathrm{MS}\right),\left(\mathrm{S}_{3} \mathrm{MS}\right)$, seeds treated with $60 \%$ concentrated tetraoxosulphate (V1) acid $\left(\mathrm{H}_{2} \mathrm{SO}_{4}\right)$ for 10 minutes $\left(\mathrm{A}_{10}\right)$ and sowed in $\mathrm{S}_{1}, \mathrm{~S}_{2}, \mathrm{~S}_{3}$ $\left(\mathrm{S}_{1} \mathrm{~A}_{10}\right),\left(\mathrm{S}_{2} \mathrm{~A}_{10}\right)$ and $\left(\mathrm{S}_{3} \mathrm{~A}_{10}\right)$ germinated first, 5 days after sowing (DAS), while the untreated soil (C) germinated last, 9 DAS. $A_{10}$ gave $(100 \%)$ germination, while, $A_{10}$ in an untreated soil (C) was the least $(65 \%)$. There was no significant effect among soil media on plant height $(\mathrm{PH})$ wet weight of root (WWR), dry weight of root (DWR) and net assimilation rate (NAR). Meanwhile, pre-germination treatment of MS had higher significant values $(8.30,31.10)$ on $\mathrm{PH}$ at 2,12 weeks after sowing (WAS), $(0.51,1.20)$ on (WWR) at 6,12 WAS, $(0.10,0.13,0.24)$ on (DWR) at 2-6 WAS and (0.08) on (NAR) at 6-4 WAS respectively. Seeds soaked in water for 24 hours $\left(\mathrm{S}_{24 \mathrm{~h}}\right)$ also had significant effect (0.53) on DWR at 10 WAS. It is concluded and recommended that, mechanically scarified seeds at the micropyle was the effective treatment for breaking dormancy of $T$. indica seeds.
\end{abstract}

Keywords: Seed scarification, Tetraoxosulphate (V1) acid, Dormancy, Sowing, Root

\section{Introduction}

Tamarindus indica (commonly known as Tamarind) is a multipurpose tree of the tropics variously used as food, chemical, in pharmaceutical and textile industries, or as fodder, timber and fuel (Pugalenthi et al. 2004). T. indica has a rich plant biodiversity, with many of the plants having medicinal uses. Such a rich biodiversity could be easily lost due to over exploitation (Afolayan and Adebola 2004). However, to the domestication of this important species and its subsequent integration into the agroecosystem requires the mass production of its seedlings. Seed dormancy with its poor, slow and difficult germination hampers agroforestry and afforestation efforts (Zabala 1991).

Therefore, raising seeds of agroforestry tree species has been the fundamental exploitation for both artificial and natural regeneration, which in turn provide high quality trees from where we get high quality seeds for sowing. Propagation of trees is majorly from seeds and it is vital to have a successful plantation raised from suitable and quality seeds (Oyebamiji et al. 2014). The usual process is that seeds must germinate first ant then grow seedlings. So, the seeds of $T$. indica must undergo pre-treatments so as to overcome seed dormancy embedded in it due to its hard seed coat for successful germination of its seeds putting various factors (type of substrate used, and environmental factors like oxygen, temperature and light) of germination into consideration ((Hartmann et al. 2001; Oyebamiji et al. 2014, 2019).

A suitable growing medium also provides sufficient anchorage to the plant which serves as reservoir of nutrients and water, permits oxygen diffusion to the roots and gaseous exchange between the roots and atmosphere outside the root substrate (Abad et al. 2002; Bello and Gada 2015)). It is also important to note that good and suitable nursery potting media influence the quality of seedlings and biomass production (Agbo and Omaliko 2006). Hence, the quality of seedlings obtained from a nursery has a direct effect on the establishment of any plantation, agroforestry site, a garden or an orchard (Baiyeri 2003; 2006).

Owing to these important highlighted views, it is highly necessary to identify the most appropriate pre-sowing or germination techniques suitable for raising $T$. indica seedlings under different potting media in the nursery. The objectives of this study were to evaluate the effect of pregermination techniques on the seed emergence and early growth performance of $T$. indica, determine the best sowing media suitable for $T$. indica seeds and assess shoot production of $T$. indica seedlings in a nursery.

\section{Materials and Methods Study Location}

This study was carried out in the Nursery Section of the Federal University Dutsin-Ma, Katsina State, Nigeria. Dutsin-ma is found within Latitude $12^{\circ} 27^{\prime} 18^{\prime \prime} \mathrm{N}$ and Longitude $07^{\circ} 29^{\prime} 29^{\prime \prime} \mathrm{E}$. The area receives an annual rainfall of $700 \mathrm{~mm}$, which is spread from May-September. The mean annual temperatures range from $29-31^{\circ} \mathrm{C}$, the high temperature normally occurs in April/May and the lowest in December through February (Tukur et al. 2013).

\section{Experimental Materials and Design}

The matured and processed seeds of $T$. indica seeds were purchased from Wednesday market in Dutsin-ma Local Government of Katsina State. Good and healthy seeds were sorted out by simple floatation technique following the procedure of Agbogidi and Eshegbeyi (2006). The river sand used was washed to remove all particles that might affect the proper germination of the seed. The potting mixture was prepared by sieving the top soil, river sand and cow dung with mixture ratio 1:1:1 (top soil plus river sand plus manure) into finest particles using $2 \mathrm{~mm}$ sieve. The mixture was then put inside sixty (60) bottom perforated polythene bags of $30 \mathrm{~cm}$ x $30.6 \mathrm{~cm}$ dimension. Seeds were pre-treated by mechanical scarification using sand paper (emery cloth), seeds soaking in water at room temperature for 24 hours, seeds soaking in $60 \%$ concentrated tetraoxosulphate (VI) $\left(\mathrm{H}_{2} \mathrm{SO}_{4}\right)$ respectively. The total number of six hundred (600) viable seeds were pre-treated, and 10 seeds each were sowed in each polythene bag, making the total of 150 seeds per replicate. The seeds were sown at a depth of $2.0 \mathrm{~cm}$ in all the treatments. 
Watering was done regularly to avoid losses of seedlings. The polythene bags were kept weed free throughout the experiment. Seedling emergence was observed to have occurred once the plumule attained a height of at least $1 \mathrm{~cm}$ above the surface of the soil following the procedure of Ugese et al. (2007). The seedlings were observed for 12 weeks after germination (WAG) to monitor growth morphology and physiology of plant height, wet and dry weight of root and net assimilation rate respectively.

The experiment was laid in $3 \times 5$ factorial in Completely Randomized Design (CRD) arrangement with four replicates. The factors were; sowing media and pregermination treatments which includes: top soil $\left(S_{1}\right)$, river sand $\left(\mathrm{S}_{2}\right)$, top soil plus river sand plus manure (cow dung) $\left(\mathrm{S}_{3}\right)$; and mechanical scarification of seeds at the micropyle (MS), seeds soaked in water at room temperature for 24 hours $\left(\mathrm{S}_{24 \mathrm{~h}}\right)$, seeds soaked in $60 \%$ concentrated $\mathrm{H}_{2} \mathrm{SO}_{4}$ for five (5) minutes ( $\mathrm{A}_{5}$ ), seeds soaked in $\mathrm{H}_{2} \mathrm{SO}_{4}$ for ten (10) minutes $\left(\mathrm{A}_{10}\right)$ and no treatment (Control) $(\mathrm{C})$ respectively.

\section{Data Collection}

Record of data of the experiment were taken at intervals of two (2) weeks to access different parameters which include:

Days of Emergence: The number of days for sprouting from each pot was observed and recorded.

Germination Percentage (\%): the percentages of germination was derived by dividing the total number of seed germinated by the total number of seed sown and then multiply by 100 , the formula is estimated below:

Germination percentage $=\underline{\text { Number of seed germinated }} \times 100$ Total number of seeds sown

Plant Height (cm): The height of five seedlings from each pot were measured from the root collar to the tip of the terminal shoot using ruler in $(\mathrm{cm})$.

Wet and Dry Weight of Root (g): One seedling from each pot was carefully uprooted washed and matter weight of root were obtained. Sensitive weighing scale was used to measure the initial wet weight of the root. After the wet weight has been taken, root components were placed in the oven and dried at $75^{\circ} \mathrm{C}$ for several days until constant weight was reached when the biomass was fully dried. The dried weight of biomass (roots) were then measured and recorded.

Net Assimilation Rate (NAR): The NAR is a measure of the amount of photosynthetic product going into plant materials i.e. it is the estimate of net photosynthetic carbon assimilated by photosynthesis minus the carbon lost by respiration. The NAR can be determined by measuring plant dry weight and leaf area periodically during growth and is commonly reported as grams of dry weight increase per square centimetre of leaf surface per week. This is also called a unit leaf rate because the assimilatory area includes only the active area in measuring the rate of dry matter production. For calculating NAR, leaf area of individual plant has to be used but not leaf area index.

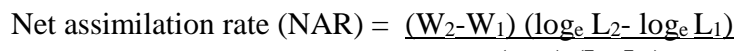
$\left(\mathrm{t}_{2}-\mathrm{t}_{1}\right)\left(\mathrm{L}_{2}-\mathrm{L}_{1}\right)$

$\mathrm{L}_{1}$ and $\mathrm{W}_{1}=$ are leaf area and dry weight of plant at time $\mathrm{t}_{1}$, and $\mathrm{L}_{2}$ and $\mathrm{W}_{2}$ are leaf area and dry weight of plants at time $t_{2}$

\section{Data Analysis}

Data were analyzed using Analysis of Variance (ANOVA) with the statistical Analysis System (SAS 2003) at $5 \%$ level of significance to determine differences in the treatment effect. The Fisher's Least Significant Difference (F- LSD; $\mathrm{P} \leq 0.05$ ) was used to separate the means of differences among the treatments.

\section{Results}

\section{Days of Emergence}

Seeds mechanically scarified (MS) and seeds treated with tetraoxosulphate (VI) acid $\left(\mathrm{H}_{2} \mathrm{~S}_{4}\right)$ for 5 minutes had the lowest days of emergence at (5) DAS and seeds not treated $(\mathrm{C})$ had the highest days of emergence in top soil + river sand + manure in 1: 1: $1\left(\mathrm{~S}_{3}\right)$ (Figure 1).

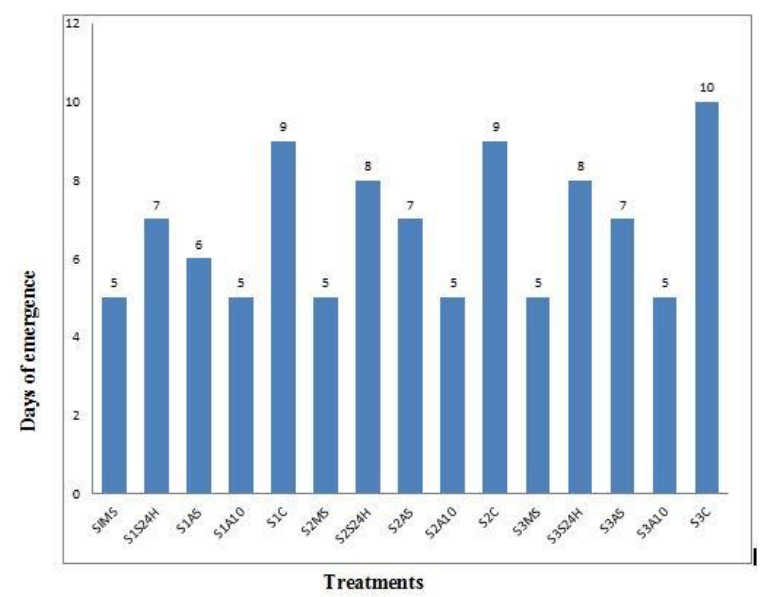

Figure 1: Showing days of emergence of Tamarindus indica seeds after sowing

\section{Germination Percentage (\%)}

Seeds treated with tetraoxosulphate (VI) acid $\left(\mathrm{H}_{2} \mathrm{SO}_{4}\right)$ for 10 minutes $\left(\mathrm{A}_{10}\right)$ sowed in river sand $\left(\mathrm{S}_{2}\right)$ had the highest germination percentage $(100 \%)\left(\mathrm{S}_{2} \mathrm{~A}_{10}\right)$ follow by seeds mechanically scarified (MS) in top soil $\left(\mathrm{S}_{1}\right)$ had $(97.5 \%)$ $\left(\mathrm{S}_{1} \mathrm{M}_{\mathrm{S}}\right)$ and the lowest is the seeds not treated (C) with germination percentage of $\left(65 \%\right.$ in top soil $\left(\mathrm{S}_{1}\right)\left(\mathrm{S}_{1} \mathrm{C}\right)$ (Figure 2).

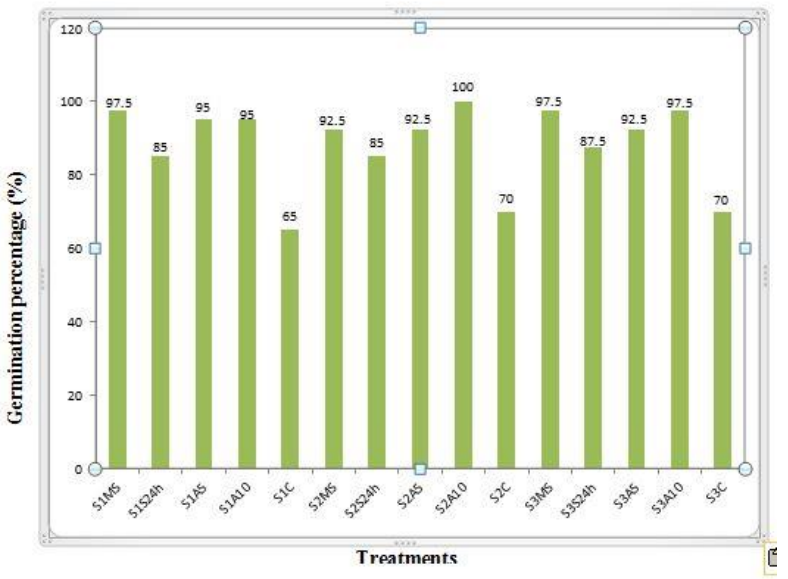

Figure 2: Showing germination percentage (\%) of Tamarindus indica seeds after sowing

\section{Plant Height (cm)}

There was no significant effect on plant height across all the period of the experiment by the various soil media. However, seeds mechanically scarified at the micropyle had significantly higher values $(8.30,31.10)$ on plant height at 2 and 12 WAS respectively among other treatments (Table 1 ). 
Table 1: Response of various soil media and pre-germination treatments on plant height at interval of 2 WAS

\begin{tabular}{|c|c|c|c|c|c|c|}
\hline \multirow[b]{2}{*}{ Treatment } & \multicolumn{6}{|c|}{ Plant height } \\
\hline & 2WAS & 4 WAS & 6 WAS & 8 WAS & 10WAS & 12 WAS \\
\hline \multicolumn{7}{|c|}{ Soil media } \\
\hline $\mathbf{S}_{1}$ & 7.70 & 13.30 & 18.02 & 22.22 & 26.02 & 30.20 \\
\hline $\mathbf{S}_{2}$ & 8.13 & 13.52 & 18.10 & 22.03 & 25.80 & 30.32 \\
\hline $\mathbf{S}_{\mathbf{3}}$ & 7.94 & 13.32 & 18.0 & 22.23 & 25.90 & 30.20 \\
\hline $\mathrm{SE} \pm$ & 0.264 & 0.450 & 0.457 & 0.521 & 0.595 & 0.671 \\
\hline \multicolumn{7}{|c|}{ Pre-germination treatments } \\
\hline MS & $8.30^{\mathrm{a}}$ & 13.80 & 18.63 & 22.82 & 26.70 & $31.10^{\mathrm{a}}$ \\
\hline $\mathbf{S}_{\mathbf{2 4 h}}$ & $7.50^{\mathrm{c}}$ & 12.72 & 17.50 & 22.00 & 25.13 & $30.10^{\mathrm{ab}}$ \\
\hline $\mathbf{A}_{5}$ & $7.63^{\mathrm{bc}}$ & 14.10 & 18.34 & 22.60 & 26.40 & $30.81^{\mathrm{a}}$ \\
\hline $\mathbf{A}_{10}$ & $8.10^{\mathrm{ab}}$ & 13.20 & 17.60 & 21.60 & 25.73 & $29.40^{\mathrm{b}}$ \\
\hline C & $8.13^{\mathrm{ab}}$ & 13.13 & 17.80 & 21.80 & 25.43 & $29.80^{\mathrm{ab}}$ \\
\hline $\mathrm{SE} \pm$ & 0.330 & 0.578 & 0.586 & 0.671 & 0.768 & 0.861 \\
\hline
\end{tabular}

Means followed by the same letters within the same column and treatment are not significantly different at $5 \%$ level of probability using Least Significant Difference (LSD). S1=Topsoil; S2=River sand; S3=Top soil + River sand + Manure; MS: Mechanical scarification, S24h: Seeds soaked in water for 24 hours, A5: Seeds soaked in Tetraoxosulphate (VI) acid for 5 minutes, A10: Seeds soaked in Tetraoxosulphate (VI) acid for 10 minutes, C: Seeds not pretreated; SE \pm : Standard Error.

\section{Wet Weight of Root (g)}

Seed sowed in soil media had no significant effect on wet weight of root across all the period of the experiment. Meanwhile, seeds mechanically scarified (MS) had significantly higher values $(0.51$ and 1.20$)$ on wet weight of root at 6 and 12 WAS. (Table 2).

Table 2: Response of various soil and pre-germination treatments on wet weight root at interval of 2 WAS

\begin{tabular}{|c|c|c|c|c|c|c|}
\hline \multirow{2}{*}{ Treatment } & \multicolumn{6}{|c|}{ Plant height } \\
\hline & t $\overline{2 W A S}$ & 4 WAS & 6 WAS & 8 WAS & 10WAS & 12 WAS \\
\hline \multicolumn{7}{|c|}{ Soil media } \\
\hline $\mathbf{S}_{1}$ & 0.20 & 0.30 & 0.44 & 0.82 & 1.00 & 1.20 \\
\hline $\mathbf{S}_{\mathbf{2}}$ & 1.53 & 0.30 & 0.50 & 0.83 & 0.93 & 1.20 \\
\hline $\mathbf{S}_{\mathbf{3}}$ & 0.20 & 0.30 & 0.50 & 0.83 & 1.00 & 1.20 \\
\hline $\mathrm{SE} \pm$ & 0.455 & 0.012 & 0.019 & 0.027 & 0.037 & 0.021 \\
\hline \multicolumn{7}{|c|}{ Pre-germination treatments } \\
\hline MS & 0.22 & 0.30 & $0.51^{\mathrm{a}}$ & 0.83 & $0.99^{\mathrm{a}}$ & $1.20^{\mathrm{a}}$ \\
\hline $\mathbf{S}_{\mathbf{2 4 h}}$ & 0.20 & 0.30 & $0.45^{\mathrm{b}}$ & 0.77 & $1.00^{\mathrm{a}}$ & $1.13^{\mathrm{b}}$ \\
\hline $\mathbf{A}_{5}$ & 2.41 & 0.30 & $0.43^{\mathrm{b}}$ & 0.83 & $0.97^{\mathrm{ab}}$ & $1.18^{\mathrm{ab}}$ \\
\hline $\mathbf{A}_{10}$ & 0.20 & 0.30 & $0.42^{\mathrm{b}}$ & 0.85 & $0.98^{\mathrm{ab}}$ & $1.17^{\mathrm{ab}}$ \\
\hline C & 0.20 & 0.30 & $0.47^{\mathrm{ab}}$ & 0.86 & $0.86^{\mathrm{b}}$ & $1.18^{\mathrm{ab}}$ \\
\hline $\mathrm{SE} \pm$ & 0.64 & 0.27 & 0.014 & 0.034 & 0.047 & 0.026 \\
\hline
\end{tabular}

Means followed by the same letters within the same column and treatment are not significantly different at $5 \%$ level of probability using Least Significant Difference (LSD). $\mathbf{S}_{\mathbf{1}}=$ Topsoil; $\mathbf{S}_{2}=$ River sand; $\mathbf{S}_{3}=$ Top soil + River sand + Manure; MS: Mechanical scarification, $\mathbf{S}_{24 h}$ : Seeds soaked in water for 24 hours, As: Seeds soaked in Tetraoxosulphate (VI) acid for 5 minutes, $\mathbf{A}_{\mathbf{1 0}}$ : Seeds soaked in Tetraoxosulphate (VI) acid for 10 minutes, C: Seeds not pretreated; $\mathbf{S E} \pm$ : Standard Error.

\section{Dry Weight of Root (g)}

Seed sowed in soil different media had no significant effect on dry weight of root across all the period of the experiment. Nevertheless, seeds mechanically scarified (MS) and seeds soaked in water for 24 hours $\left(\mathrm{S}_{24 \mathrm{~h}}\right)$ had significantly higher values $(0.10,0.13,0.24)$ and $(0.53)$ on dry weight of root at 2-6 WAS and 10 WAS respectively (Table 3).

Table 3: Response of various soil and pre-germination treatments on dry weight root at interval of 2 WAS

\begin{tabular}{lllllll}
\hline \multicolumn{6}{c}{ Dry weight root } \\
\hline Treatment & 2WAS & 4 WAS & 6WAS & 8 WAS & 10 WAS & 12 WAS \\
\hline Soil media & & & & & & \\
$\mathbf{S}_{\mathbf{1}}$ & 0.08 & 0.11 & 0.21 & 0.47 & 0.49 & 0.62 \\
$\mathbf{S}_{\mathbf{2}}$ & 0.08 & 0.11 & 0.22 & 0.43 & 0.48 & 0.62 \\
$\mathbf{S}_{\mathbf{3}}$ & 0.09 & 0.12 & 0.22 & 0.42 & 0.52 & 0.63 \\
$\mathrm{SE} \pm$ & 0.006 & 0.005 & 0.011 & 0.016 & 0.021 & 0.011
\end{tabular}

Pre-germination treatments

$\begin{array}{lllllll}\text { MS } & 0.10^{\mathrm{a}} & 0.13^{\mathrm{a}} & 0.24^{\mathrm{a}} & 0.42 & 0.52^{\mathrm{ab}} & 0.63 \\ \mathbf{S}_{24 \mathrm{~h}} & 0.08^{\mathrm{ab}} & 0.12^{\mathrm{ab}} & 0.21^{\mathrm{ab}} & 0.39 & 0.53^{\mathrm{a}} & 0.60 \\ \mathbf{A}_{5} & 0.08^{\mathrm{b}} & 0.11^{\mathrm{ab}} & 0.20^{\mathrm{b}} & 0.42 & 0.50^{\mathrm{ab}} & 0.63 \\ \mathbf{A}_{10} & 0.08^{\mathrm{ab}} & 0.11^{\mathrm{b}} & 0.20^{\mathrm{b}} & 0.44 & 0.40^{\mathrm{ab}} & 0.63 \\ \mathbf{C} & 0.08^{\mathrm{b}} & 0.11^{\mathrm{b}} & 0.23^{\mathrm{ab}} & 0.44 & 0.45^{\mathrm{b}} & 0.62 \\ \mathrm{SE} \pm & 0.007 & 0.006 & 0.014 & 0.021 & 0.026 & 0.015\end{array}$

Means followed by the same letters within the same column and treatment are not significantly different at $5 \%$ level of probability using Least Significant Difference (LSD). $\mathbf{S}_{\mathbf{1}}=$ Topsoil; $\mathbf{S}_{2}=$ River sand; $\mathbf{S}_{3}=$ Top soil + River sand + Manure; MS: Mechanical scarification, $\mathbf{S}_{24 \mathrm{~h}}$ : Seeds soaked in water for 24 hours, A5: Seeds soaked in Tetraoxosulphate (VI) acid for 5 minutes, $\mathbf{A}_{10}$ : Seeds soaked in Tetraoxosulphate (VI) acid for 10 minutes, C: Seeds not pretreated; $\mathbf{S E} \pm$ : Standard Error.

\section{Net Assimilation Rate (NAR)}

There was no significant effect of soil media on net assimilation rate across all the period of the experiment. However, seeds mechanically scarified had significantly higher value (0.08) on net assimilation rate at 6-4 WAS (Table 4).

Table 4: Response of various soil and pre-germination treatments on net assimilation rate

\begin{tabular}{|c|c|c|c|c|c|}
\hline \multirow[b]{2}{*}{ Treatment } & \multicolumn{4}{|c|}{ Net assimilation rate } & \multirow[b]{2}{*}{$\begin{array}{l}12-10 \\
\text { WAS }\end{array}$} \\
\hline & $\begin{array}{l}4-2 \\
\text { WAS }\end{array}$ & $\begin{array}{l}6-4 \\
\text { WAS }\end{array}$ & $\begin{array}{l}8--6 \\
\text { WAS }\end{array}$ & $\begin{array}{l}10-8 \\
\text { WAS }\end{array}$ & \\
\hline \multicolumn{6}{|l|}{ Soil media } \\
\hline $\mathbf{S}_{1}$ & 0.03 & 0.07 & 0.14 & 0.05 & 0.05 \\
\hline $\mathbf{S}_{2}$ & 0.08 & 0.08 & 0.15 & 0.04 & 0.06 \\
\hline $\mathbf{S}_{\mathbf{3}}$ & 0.04 & 0.07 & 0.14 & 0.05 & 0.05 \\
\hline $\mathrm{SE} \pm$ & 0.006 & 0.005 & 0.074 & 0.008 & 0.005 \\
\hline
\end{tabular}

\section{Pre-germination treatments}

$\begin{array}{llllll}\text { MS } & 0.03 & 0.08^{\mathrm{a}} & 0.14 & 0.06 & 0.05 \\ \mathbf{S}_{\mathbf{2 4 h}} & 0.02 & 0.08^{\mathrm{ab}} & 0.13 & 0.06 & 0.04 \\ \mathbf{A}_{5} & 0.04 & 0.07^{\mathrm{ab}} & 0.15 & 0.06 & 0.05 \\ \mathbf{A}_{\mathbf{1 0}} & 0.03 & 0.06^{\mathrm{b}} & 0.15 & 0.04 & 0.05 \\ \mathbf{C} & 0.03 & 0.08^{\mathrm{ab}} & 0.14 & 0.04 & 0.06 \\ \mathrm{SE} \pm & 0.008 & 0.006 & 0.009 & 0.010 & 0.019\end{array}$

Means followed by the same letters within the same column and treatment are not significantly different at $5 \%$ level of probability using Least Significant Difference (LSD). $\mathbf{S}_{1}=$ Topsoil; $\mathbf{S}_{2}=$ River sand; $\mathbf{S}_{3}=$ Top soil + River sand + Manure; MS: Mechanical scarification, $\mathbf{S}_{24 \mathrm{~h}}$ : Seeds soaked in water for 24 hours, As: Seeds soaked in Tetraoxosulphate (VI) acid for 5 minutes, A10: Seeds soaked in Tetraoxosulphate (VI) acid for 10 minutes, C: Seeds not pretreated; $\mathbf{S E} \pm$ : Standard Error. 


\section{Discussion}

Of the results, there was no significant difference $(\mathrm{P} \leq$ 0.05 ) among the soil media on plant height, wet and dry matter weight of root and net assimilation rate. This is an indication that soil media used do not interfere with germination of Tamarindus indica seeds as long as correct and adequate pre-sowing treatments were carried out on them. Seeds that mechanically scarified were significant on plant height at 2 and 12 WAS, wet weight of root at 6 and 12 WAS and dry weight of root at 2-6 WAS and net assimilation rate at 6-4 WAS respectively.

Seed germination of $T$. indica seeds started 5 days after sowing (DAS). Mechanically scarified seeds sowed in top soil $\left(\mathrm{S}_{1} \mathrm{MS}\right)$, seeds treated with $60 \%$ concentrated tetraoxosulphate $(\mathrm{V} 1)$ acid $\left(\mathrm{H}_{2} \mathrm{SO}_{4}\right)$ for 10 minutes and sowed in top soil $\left(\mathrm{S}_{1} \mathrm{~A}_{10}\right)$, mechanically scarified seeds sowed in river sand $\left(\mathrm{S}_{2} \mathrm{MS}\right)$, seeds treated with $\mathrm{H}_{2} \mathrm{SO}_{4}$ for 10 minutes and sowed in river sand $\left(\mathrm{S}_{2} \mathrm{~A}_{10}\right)$, mechanically scarified seeds sowed in top soil plus river sand plus manure ( $\mathrm{S}_{3} \mathrm{MS}$ ) and seeds treated with $\mathrm{H}_{2} \mathrm{SO}_{4}$ for 10 minutes and sowed in top soil plus river sand plus manure $\left(\mathrm{S}_{3} \mathrm{~A}_{10}\right)$ germinated first, 5 DAS, while the untreated soil (C) germinated last, 9 DAS. A 10 gave $(100 \%)$ germination, while, $\mathrm{A}_{10}$ in an untreated soil (C) was the least $(65 \%)$. This implies that the difference in the days of emergence and germination rate of the seeds in each treatment was a result of pre-germination treatments carried out on the seeds. Dormancy in seeds was overcome, speeding up their germination as also stated by (Roshetko 1995; Agboola 2002).

Seeds of T. indica treated with $60 \%$ tetraoxosulphate (VI) acid $\left(\mathrm{H}_{2} \mathrm{SO}_{4}\right)$ for 10 minutes $\left(\mathrm{A}_{10}\right)$ in soil media of top soil plus river sand plus manure $\left(\mathrm{S}_{3}\right)$ had the highest germination percentage $\left(\mathrm{S}_{3} \mathrm{~A}_{10}\right)(100 \%)$ in all treatments and soil media, followed by the seeds mechanically scarified (MS) in soil media of top soil plus river sand plus manure $\left(\mathrm{S}_{3}\right)(97.5 \%)$ and seeds not treated at all (control) $(\mathrm{C})$ gave the least percentage in top soil $\left(\mathrm{S}_{1}\right)(65 \%)$ of germination respectively. These results indicated that seeds soaked in concentrated acid for a short time tend to show better germination performance and it also improves seed germination rate (Olatunji et al. 2012). It means that seeds that stayed longer in acid have the risk of damaging their cotyledon and this will eventually hamper germination as reported by Ariana et al. (2011).

It was generally observed that mechanically scarified seeds had higher effect on plant height, wet and dry weight of root and net assimilation rate. This is possible as a result of abrasion effect that has taken off the hard seed coat of the Tamarindus seeds and thereby provided access for easy penetration of water and oxygen and thereby improved rapid germination of the seeds (Oyebamiji et al. 2019). Hence, the emergence of the seeds was faster in the seeds mechanically scarified and consequently affected its complete germination leading to highest germination percentage $(100 \%)$ and is in agreement with Oyebamiji et al. (2014) report who said that seeds scarified at the micropyle region experience faster germination of seeds and higher percentage rate.

\section{Conclusions}

Since the seed is fundamental in Silviculture for both artificial and natural regeneration, dormancy of the viable seeds has to be overcome for massive and improved tree establishment. It is obvious from this study that the mechanical scarification of $T$. indica seeds with sand paper at the micropyle was an effective treatment for breaking dormancy of $T$. indica seeds. It is therefore concluded that seeds mechanically scarified in all the soil media had the shortest days of emergence with five 5 DAS across all the soil media, while seeds not pre-treated gave the longest days of emergence with 10 DAS. Mechanically scarified seeds at the micropyle showed the highest values $(97.5 \%)$ while seeds not treated (control) gave the least germination percentage $(65 \%)$. It is then recommended that mechanically scarified seeds at the micropyle should be used by farmers, foresters and tree planter as the effective treatment for breaking dormancy of $T$. indica seeds for forest establishment.

\section{References}

Abad M, Noguera P, Puchades R, Maquieira A, Noguera V (2002). Physico-chemical and chemical properties of some coconut dusts for use as a peat substitute for containerized ornamental plants. Bioresources Technonology. 82(3): 241-245.

Afolayan AJ, Adebola PO (2004). In vitro propagation: A biotechnological tool capable of solving the problem of medicinal plants decimation in South Africa. African Journal of Biotechnology. 3: 683-687.

Agbo CU, Omaliko CM (2006) Initiation and growth of shoots of Gongronema latifolia Benth stem cuttings in different rooting media. African Journal of Biotechnology. 5(5): 425-428.

Agbogidi OM, Bosah BO, Eshegbeyi OF (2007). Effects of Acid Pre-Treatment on the Germination and Seedling Growth of African Pear (Dacryodes edulis Don. G. Lam. H.J.). International Journal of Agricultural Resources. 2(11): 952-958.

Agboola DA (2002). The effect of fruit fermentation and some pre-treatments of the germination of seeds of Spondias mombin (Linn). An International Journal of Agricultural Science, Environment and Technology (ASSET). 1(2): 47-52.

Ariana OM, Ojas R, Re'chiga A, Aria K, Guilar MAA, Jardan G, Olubov Maria, Andujano GM (2011). Effect of Gibberellin Acid on germination of seeds of five species of cacti from the chihuahuan desert, Northern mexico. The Southwestern Naturalist. 56 (3): 393-400.

Baiyeri KP (2003) Evaluation of nursery media for seedling emergence and early seedling growth of two tropical tree species. Moor Journal of Agricultural Resources. 4: 60-65.

Baiyeri KP (2006) Seedling emergence and growth of pawpaw (Carica papaya) grown under different coloured shade polyethylene. International Agrophysics. 20: In press.

Bello AG, Gada ZY (2015) Germination and early growth assessment of Tamarindus indica L in Sokoto State, Nigeria. International Journal of Forestry Research. 2015(634108): 5.

Hartmann HT, Kester DE, Davies Ft, Geneve RL (2001). Plant propagation, principles and practices ( 7 th edn), prentice hall publishers, New Jersey, USA.

Olatunji D, Maku JO, Odumefun OP (2013). "The effect of pre-treatments on the germination and early seedlings growth of Acacia auriculiformis Cunn. Ex. Benth," African Journal of Plant Science. 7: 325-330.

Oyebamiji N A, Ogor A A, Abdulrahman H D. 2019. Effect of Different Growing Soil Media on Seed Germination and Growth of Tamarind as Influenced by Seed Dormancy Breaking Approaches. International 
Journal of Environmental Sciences and Natural Resources.17(1): $\quad 555954 . \quad$ DOI: 10.19080/IJESNR.2019.17.555954.

Oyebamiji NA, Fadimu OY, Adedire MO (2014). Best pre-germination techniques on Spondias mombin Linn, seed for plantation establishment. American- European Journal of Agriculture and Environmental Science. 14(6): 575-579.

Pugalenthi M, Vadivel V, Gurumoorthi P, Janardhanan K (2004). Composative nutritional evaluation of little known legumes, Tamarindus indica, Erythirna indica and Sesbania bispinosa. Tropical and Subtropical Agro-ecosystem. 4: 107-23.

Roshetko JM (1995). A Publication of the Agroforestry information services. Winrock International Institute for Agricultural Development. 402p.

SAS (2003). Statistical Analysis Systems. SAS release 9.1 for windows, SAS Institute. Cary, N.C USA. 949p.

Tukur R, Adamu GK, Abdulrahid I, Rabi’u M (2013). Indigenous trees inventory and their multipurpose uses in Dutsin-Ma area, Katsina State. European Scientific Journal. 9(11): 288-300.

Uwaegbute G (2006). Agroforestry development projects finding and recommendation food and agriculture: ROM OF/NIR/54/UNDP/FAO.PP.55.

Zabala NQ (1991). Plantation Silviculture. Development of Professional Education in The

Forestry Sector, Bangladesh. UNDP/FAO/BGD/85/011, Field Document No. 19. IFCU, FAO, UN. 234p. 